\title{
Integrated management of late blight of potato
}

\author{
Mehi Lal ${ }^{1 *}$, Saurabh Yadav ${ }^{1}$, Sanjeev Sharma ${ }^{2}$, B. P. Singh ${ }^{1}$ and S. K. Kaushik ${ }^{3}$ \\ ${ }^{1}$ ICAR-Central Potato Research Institute, Campus Modipuram, Meerut- 250110 (Uttar Pradesh), INDIA \\ ${ }^{2}$ ICAR- Central Potato Research Institute, Shimla -170001 (Himachal Pradesh), INDIA \\ ${ }^{3}$ ICAR-National Bureau of Plant Genetic Resources, New Delhi - 110012, INDIA \\ *Corresponding author. E-mail: mehilalonline@gmail.com
}

Received: December 10, 2016; Revised received: March 19, 2017; Accepted: August 25, 2017

\begin{abstract}
Late blight of potato is the major biotic constraint responsible for reduction in yield and quality of the potato crop. Globally, late blight is managed through application of multiple fungicidal chemical sprays affecting both human health and environment.Now a days, methods of biological control are gaining importance as these are nontoxic and also environment friendly. However, Phytophthora infestans multiplies very fast; therefore, biological control method alone is not a viable option to manage late blight. Hence, integration of both methods is essential. Eleven treatments consisting of biocontrol agents and fungicides were evaluated against the late bight in three consecutive seasons (2011-12, 2012-13, 2013-14) at ICAR-CPRIC, Modipuram. Meerut. The results revealed that the treatments ( T1 to T10) are effective for managing the disease up to certain level; however, lowest average disease severity $(27.89 \%)$ was recorded in treatment when Bacillus subtilis (B5-0.25\%) + Trichoderma viride (TV-0.7\%) was applied before disease appearance followed by cymoxanil8+mancozeb 64\%WP (0.3\%) at onset of late blight and one more spray of B5+ TV after seven days. The next best treatment was application of B5+ TV before appearance of disease followed by metalaxyl $8+$ mancozeb $64 \% \mathrm{WP}(0.25 \%)$ at onset of late blight and one more spray of B5+ TV against control (average disease severity 91.94\%) with higher yield also except the treatment of three spray of mancozeb $75 \%$ WP $(0.2 \%)$. These treatments could be integrated in farmer practices.
\end{abstract}

Keywords: Bacillus, Fungicides, Late blight, Potato, Trichoderma

\section{INTRODUCTION}

Late blight of potato caused by an oomycete Phytophthora infestans (Mont.) de Bary is the most destructive disease of potato in hills and plain regions of India and caused yield losses up to $95 \%$ in epidemic conditions (Lal et al., 2015). Recently, reduction in $10-15 \%$ yield of potato was estimated due to occurrence of late blight in India on over all basis (Lal et al., 2016). Management strategies for its effective control include use of host resistance, chemicals, biocontrol, forecasting, sanitation and even disease escape (Wastie, 1991; Singh and Sharma, 2013). It is observed that within a decade host resistance is broken down with subsequent increase in level of susceptibility to late blight. Generally, no such cultivar allows the commercial cultivation of potato without fungicides protection. The most commonly used fungicides by farmers are mancozeb $75 \mathrm{WP}(0.2 \%)$, cymoxanil8+mancozeb64 WP $(0.3 \%)$, metalxayl $8+64$ WP $(0.25 \%)$,dimethmorph $50 \% \mathrm{WP}(0.2 \%)$ and fenomidon $10+$ mancozeb $50 \mathrm{WG}(0.3 \%)$. Amongst these, mancozeb comes under group of EBDC (Ethylenebisdithiocarbamate) which break down into ethylenethiourea (ETU), which is a type IIB carcinogen and antithyriod compound (Panganiban et al.,2004). Moreover, development of metalaxyl re- sistance in $P$. infestans races globally had made this systemic fungicide redundant and so far farmers are waiting for its apt replacement. The indiscriminate use of these chemicals not only poses a serious threat to the environment but also to the human health. Biological control by antagonists has attracted much attention because of being eco-friendly to environment and the crop (Harmendez et al., 2005). Recent years have witnessed the increasing popularity of biological control agents as an alternative to fungicides (Glare et al., 2012). Many bio-agents i.e. Trichoderma viride, Penicillium virdicatum, P. aurantiogiseum, Chetomium brasilense (Gupta et al., 2004), Acremonium strictum (CPRI, 1999), Myrothecium varrucaria and P. aurantiogriseum (Roy et al., 1991) showed antagonistic effect against $P$. infestans in lab studies. The antagonistic activities of Pseudomonas fluorescens, Pseudomonas sp. Aspergillus flavus, A. niger, Penicillium sp., T. virens and $T$. harzianum showed positive inhibition of mycelial growth of $P$. infestans, Fusarium spp and Rhizoctonia solani under in vitro conditions (Lal et al., 2013). Bacillus species were used for managing late blight disease of potato in vitro (Sunaina et al., 2005;). Different species of Trichoderma were also evaluated and reported effective against late blight of potato under field condition (Yuan-Hang et al., 2014; Yao et 
al., 2016). The effectiveness of bio-agents viz, Trichoderma, Bacillus and Pseudomonas were also reported against $P$. infestans under field condition (Basu, 2009; EI-Naggar et al., 2016).

Since late blight spreads very fast in the fields when the environmental conditions are conducive, therefore, management of late blight through bioagents only may not be effective. Therefore, present studies were conducted for three consecutive years (2011-12, 2012-13, and 2013-14) in combination of bio-agent with fungicides against late blight with the objective to reduce the number of fungicidal sprays without compromising the economic yield.

\section{MATERIALS AND METHODS}

The experiments were conducted on cv. Kufri Bahar which is popular with farmers but highly susceptible to late blight. Eleven following treatments were selected: T1: (Bacillus subtilis-B5- $0.25 \%$ + Trichoderma virideTV- $0.7 \%)-3$ spray

T2: (B. subtilis + T.viride)-2 spray

T3: (B. subtilis + T.viride)-1 spray

T4: Spray of (B5+ TV) before appearance of disease followed by metalaxyl $8+$ mancozeb $64 \%$ WP $(0.25 \%)$ at onset of late blight and one more spray of B5+ TV.

T5: Spray of (B5+ TV) before appearance of disease followed by cymoxanil 8 +mancozeb $64 \%$ WP $(0.3 \%)$ at onset of late blight followed by one more spray of B5+ TV.

T6: Spray of (B5+ TV) before appearance of disease followed by mancozeb $75 \% \mathrm{WP}(0.2 \%)$ at onset of late blight followed by one more spray of B5+ TV.

T7: Spray of (B5+ TV) before appearance of disease followed by before- Neem oil based azadirechtin $0.15 \%(10 \%)$ at onset of late blight followed by one more spray of $\mathrm{B} 5+\mathrm{TV}$

T8: Mancozeb $75 \%$ WP (0.2\%) spray before appearance of disease followed by mancozeb $75 \%$ WP $(0.2 \%)$ at onset of late blight followed by one more spray of mancozeb $75 \%$ WP $(0.2 \%)$.

T9: B. subtilis spray before appearance of disease followed by B. subtilis $\quad(0.25 \%)$ at onset of late blight followed by one more spray of $B$. subtilis $\quad(0.25 \%)$.

T10: T V $(0.7 \%)$ before appearance of disease followed by TV $(0.7 \%)$ at onset of late blight followed by one more spray of TV $(0.7 \%)$ spray before, onset and 7 days after second spray.

T11: Control without any spray.

Treatments $\mathrm{T} 1$ to $\mathrm{T} 3$ were purely bacterial and fungal antagonist, whereas T9 and T10 were purely bacterial and fungal antagonist respectively. These treatments could be applied in organic potato production system also. Treatments T4, T5, T6 used for reducing number of fungicides spray, as only one spray was used and two spray of the combination of bacterial and fungal antagonist. In treatment T7, neem formulation was used at appearance of disease instead of fungicides.
The experiments were conducted in Randomized Block Design with three replications at ICAR-CPRIC, Modipuram Meerut $\left(29.1^{\circ} \mathrm{N}, 77.92^{\circ} \mathrm{E}, 300 \mathrm{msl}\right)$ during three consecutive rabi seasons i.e. 2011-12, 2012-13, 2013-14. Tubers were planted in second week of November and crop was raised as per recommended practices of the regions. Infector rows were planted as borders of the experimental field to ensure smooth spread of late blight across the treatments. The disease was initiated by putting $0.3 \mathrm{~cm}^{2}$ filter paper discs on the lower side of leaves in infector rows in the evening. These paper discs were dipped in zoospores suspension of $P$. infestans having a concentration of $6 \times 10^{4}$ per ml.Sprinklers were used to maintain the humidity in the experimental fields. The tubers of K. Bahar were planted in a standard plot of $9 \mathrm{~m}^{2}$ size having five rows of three meters length was used per treatment keeping 60 x $20 \mathrm{cms}$ Row x Plant spacing .Spraying was started before one week initiation and the appearance of disease and in total three sprays were given at 7 days interval. Terminal disease severity was recorded after 10 days of $3^{\text {rd }}$ sprays as per the method of Henfling (1987). Data on tuber yield were also recorded at the time of harvesting. The data were subjected to standard statistical analysis using IRRISTAT software.

\section{RESULTS AND DISCUSSION}

The results revealed that the treatment T5[ B. Subtilis $+T$. viride applied before disease appearance followed by cymoxanil $8+$ mancozeb $64 \%$ WP $(0.3 \%)$ at onset of late blight and one more spray of $B$. subtilis $+T$ viride ] resulted in less disease severity $14.5,37.50$ and $31.67 \%$ along with tuber yield 34.30, 26.61 and $21.46 \mathrm{t} /$ ha during 2011, 2012 and 2013, respectively except the treatment $\mathrm{T} 8$, where three spray with mancozeb $75 \%$ WP (Table 1) were applied. This treatment was at par with $\mathrm{T} 4[\mathrm{~B}$. subtilis $(\mathrm{B} 5)+T$. viride before disease appearance followed by metalaxyl $8+$ mancozeb $64 \%$ WP $(0.25 \%)$ at onset of late blight and one more spray of $B$. subtilis (B5) $+T$. viride (TV)]. On the basis of pooled data, these treatments performed better in both reducing disease severity and increasing tuber yield. These treatments could be used for management of late blight without affecting economic yield and using less chemical sprays. The remaining eight treatments (T1, T2, T3, T6, T7, T8, T9 and T10) were also effective for reducing disease severity (39.95-76.83\%) against control (91.94\%). Many researchers have demonstrated the effectiveness of biocontrol agents alone and in combination with fungicides in management of late blight of potato and tomato both in the lab studies and under field conditions. B.subtilis and Rahnella aqatilis both strongly inhibited P.infestans on media in- vitro and provided the best rate of local protection on whole plants test and among the best rate of systemic protection (Daayf et al., 2003). Ajay and Sunaina (2005) reported $46.83-91.15 \%$ inhibition of $P$. infestans over 
Mehi Lal et al. / J. Appl. \& Nat. Sci. 9 (3): 1821 -1824 (2017)

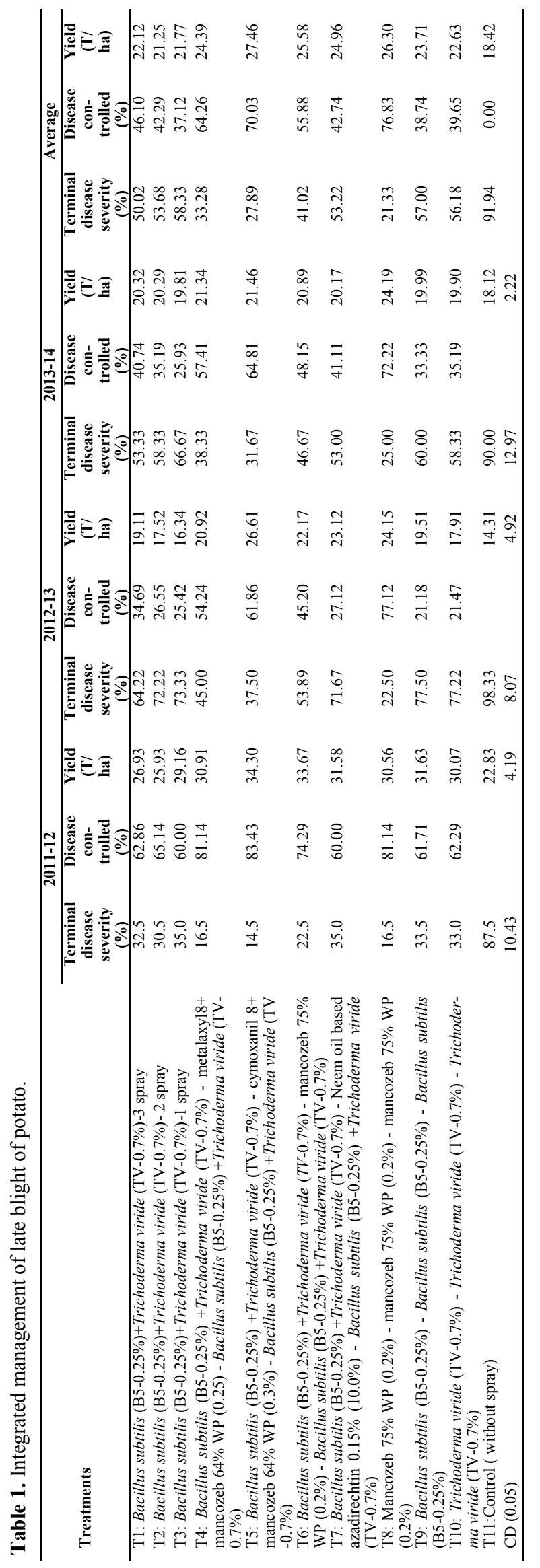

control with B. subtilis. Bacillus sp. inhibited mycelial growth of 7 plant pathogenic fungi in vitro and in vivo and the same bacterium protected tomato plants against $P$. infestans (Sadlers, 1996). Singh et al. (2010) advocated integrated management using $T$. viride+ mancozeb against late blight in tomato. Yao et al., 2016 evaluated different isolates of Trichoderma against $P$. infestans and found that Trichoderma isolates HNA 14 was most effective under both laboratory and field condition. Yuan-Hang et al., 2014 also reported that $T$. koningiopsis and $T$. asperellum were effective against $P$. infestans under both laboratory and field conditions.

The systemic/translaminar/contact fungicides are known suppressor of the late blight disease and final application of combination of bioagent at low level of inoculum further suppressed the disease in our experimental fields. Application of T.viride and B. subtilis before appearance of the disease might have activated some host defense mechanisms that may have delayed the initial establishment and spread of the disease. The defense enzymes viz., chitinase and $\beta .1,3$-glucanase activities of $B$. subtilis and T. harzianum are well reported against late blight of potato and early and late blight of tomato (El-Naggar et al., 2016; Chowdappa et al., 2013). The results of the present study clearly demonstrated that all the treatments are able to provide control of late blight to some extent as against unsprayed control. However, the treatments with only biocontrol agents used individually or together could not provide better control as compared to treatments involving fungicides along with biocontrol agents.

\section{Conclusion}

Present finding revealed that the combination of $T$. viride $(0.7 \%)+B$. subtilis $(0.25 \%)$ with three sprays, first at before appearance of late blight, second at appearance and third after appearance could be adopted for organic cultivation of potato. Moreover, treatment comprising spray of $T$. viride $(0.7 \%)+B$. subtilis $(0.25 \%)$ before late blight appearance and one spray of Cymoxanil8+mancozeb $64 \%$ WP at appearance followed by final spray of $T$. viride $(0.7 \%)+B$. subtilis $(0.25 \%)$ was highly effective for managing late blight of potato, thus saving two sprays of fungicides and reducing related costs of fungicides and labour without compromising tuber yield of potato.

\section{ACKNOWLEDGEMENTS}

Authors are grateful to Dr R. K Arora (Ex Principal Scientist, Division of Plant Protection, ICAR-CPRS, Jalandhar Punjab) for providing formulation of Trichoderma viride.

\section{REFERENCES}

Ajay, S. and Sunaina, V. (2005). Direct inhibition of Phytophthora infestans, the casual organisms of late blight 
of potato by Bacillus antagonists. Potato J., 32:179-180

Basu, A.(2009). Employing ecofriendly potato disease management allows organic tropical Indian production systems to prosper. As. J. Food Ag-Ind. Special Iss, S80S87

Chowdappa, P., Mohan Kumar, S.P., Jyothi Lakshmi, M. and Upreti K.K. (2013). Growth stimulation and induction of systemic resistance in tomato against early and late blight by Bacillus subtilis OTPB1 or Trichoderma harzianum OTPB3. Biological Cont., 65 : 109-117

CPRI. (1999). Annual Progress Report. Central Potato Research Institute, Shimla, India

Daayf, F., Adam, L, and Fernando, W.G.D. (2003). Comparative screening of bacteria for biological control of potato late blight (strain US-8), using in-vitro, detached -leaves, and whole-plant testing systems. Can J. Plant Pathol., 25:276-284

El-Naggar, M.A., Abouleid, H.Z., El-Deeb, H.M., Abd-ElKareem, F, and Elshahawy I.E. (2016). Biological control of potato late blight by means of induction systemic resistance and antagonism. R.J.P.B.C.S. 13 1338-1348

Glare, T., Caradus, J., Gelernter, W., Jackson, T., Keyhani, N., Kohl, J., Marrone, P., Morin, L.and Stewart, A. (2012). Have biopesticides come of age? Trends Biotech., 30:250-258

Gupta, H., Singh, B.P. and Mohan, J. (2004). Bio-control of late blight of potato. Potato J., 31:39-42.

Harmendez, C.J., Andrew, R. and Ferre, Y.B.J. (2005). Evaluation of foliage resistance in potato to Phytophthora infestans based on international field network. Plant Pathol, 88:8-16

Henfling, J.W. (1987). Late blight of potato: Phytophthora infestans. Technical Information Bulletin 4 (second edition revised) CIP, Lima Peru: 22p

Lal, M., Arora, R.K., Maheshwari, U., Rawal, S. and Yadav, S. (2016). Impact of late blight occurrence on potato productivity during 2013-14. Int. J. Agricult. Stat. Sci., 12 (1): 187-192

Lal, M., Singh, P.A., Tomar, S., Hussain, T., Sharma, S.,
Kaushik, S.K. and Singh, B.P. (2013). Antagonistic effect of bio-agents against three potato fungal diseases and their fungicidal sensitivity. Vegetos, 26:362-367

Lal, M., Yadav, S., Chand, S., Kaushik, S.K., Singh, B.P. and Sharma, S. (2015). Evaluation of fungicides against late blight (Phytophthora infestans) on susceptible and moderately resistant potato cultivars. Indian Phytopathol, 68:345-347

Panganiban, L., Cortes-Maramba, N., Dioquino, C., Suplido, M. L., Ho, H., Francisco-Rivera, A., \& ManglicmotYabes, A. (2004). Correlation between blood ethylenethiourea and thyroid gland disorders among banana plantation workers in the Philippines. Environ. Health Perspect, 112: 42-45

Roy, S., Singh, B.P. and Bhattacharyya, S.K. (1991). Biocontrol of late blight of potato. Phytophthora News Letter, $17: 18$

Sadlers, H.M. (1996). Use of bacteria in controlling fungal diseases. Gemuse Munchen., 32:180-181

Singh, G., Singh, V.P., Singh, B., and Kumar K. (2010). Comparative evaluation of chemical biological and integrated management strategies on late blight of tomato. Ann. Horticulture, 3:238-240

Singh, B.P. and Sharma, S. (2013). Forecasting of potato late blight. Intern J Innov Hort., 2(1):1-11

Sunaina, V., Ajay, S. and Dureja, P. (2005). Bacterial metabolites from Bacillus cereus B4 responsible for potato plant growth, Potato J., 32:187-188

Wastie, R.L. (1991). Breeding for resistance. In Advances in Plant Pathology, vol.7 Phytophthora infestans, the cause of late blight of potato, (Eds. DS.Ingram and PH Williams). London, Academic Press, 193-224.

Yao, Y., Li, Y., Chen, Z., Zheng, B., Zhang, L., Niu,B., Meng, J., Li, A., Zhang, J., and Wang, Q. (2016). Biological control of potato late blight using isolates of Trichoderma. Am. J. Potato Res. 93:33-42

Yuan-Hang,Q.U., Qi, W., Yan-Po, Y., Zhen-Lin, H. and Yan L.(2014). Antagonistic Trichoderma isolates against potato late blight caused by Phytophthora infestans. Mycosystema,33:1231-1241 